\title{
IMPROVEMENT OF AGGREGATION TECHNIQUES OF UNIVERSAL SELF-PROPELLED CHASSIS BY USING FOLDING FRAMES
}

\author{
Mikhail Podrigalo ${ }^{1}$, Volodymyr Krasnokutsky ${ }^{2}$, Serhii Selevich ${ }^{2}$, Olexander Zakapko ${ }^{1}$ \\ ${ }^{1}$ Kharkov National Automobile and Highway University, Ukraine; ${ }^{2}$ National Technical University “ \\ Kharkiv Polytechnic Institute", Ukraine \\ pmikhab@gmail.com,hvukvn62@gmail.com,sergej.selevich@gmail.com, zakapko13@ukr.net
}

\begin{abstract}
The results of the study of the possibility to improve the process of mechanized hitching of machines and tools into the center zone of self-propelled chassis, using a folding frame and a front balancing swivel axle, are presented. Research and studies that had been carried out earlier in Ukraine and other countries did not allow to solve this problem by the simpler methods. The use of a front swivel axle makes it possible to solve the problem of an automated hitching of implements and tools in the center zone, improve maneuverability and simplify the steering drive of a self-propelled chassis. The scientific novelty of this research is a dynamic model of the vehicle turning in place around one of the rear wheels, when the front axle is turned at an angle close to 90 degrees. The use of a balanced front axle can significantly reduce the moment of resistance to turning. The latter phenomenon has not been studied in the known publications. The aim of the study is to increase the maneuverability of a universal-row-crop tractor self-propelled chassis, including the process of mechanized hitching of implements and tools in the center zone when using a folding technological frame. The use of a swivel front axle allows us to get an ideal turn with any changeable front wheel track that might be changed during the operation of the vehicle. The conditions that make it possible to turn the machine around one of the rear wheels are determined.
\end{abstract}

Keywords: tractor, self-propelled chassis, front swivel axle, momentum of resistance to turning.

\section{Introduction}

Universal row-crop tractor self-propelled chassis was created with the possibility of aggregation with a wide range of hinged and mounted machines and tools. However, the limitations of the design of the technological frame and aggregation deficiencies did not make it possible to take full advantage of self-propelled tractor chassis - its versatility. Despite the numerous technical proposals, this problem has not been resolved yet.

Research on improving self-propelled chassis and its technology had been carried out in Ukraine, Latvia, Germany, Italy, USA and other countries. At some stage, this work stopped. It was connected with the difficulties to provide mechanized hitching of machines and tools in the center zone of the selfpropelled chassis.

The proposals of the article authors are aimed at solving this problem. At the same time, an integrated approach is proposed that combines an increase in the performance of a self-propelled chassis with an improvement of its maneuverability. The suggested design of the technological frame with a swivel front axle provides a mechanized hitching of machines and tools in the center zone of a selfpropelled chassis. The use of a front swivel axle will also improve the maneuverability of the selfpropelled chassis with variable front wheel tracks during the vehicle operation and also eliminate its tie rods. The tie rods are usually extendable and can change their length depending on the front wheel tracks.

Nowadays, modern publications do not fully cover the issues of turning wheeled vehicles by turning the front axle around its center. The rotation of a balanced suspended bridge around a central hinge simultaneously in two planes has not been considered in known studies, although interesting effects appear here.

This scheme allows the machine to turn around any of the rear wheels, which facilitates the mechanized hitching in the center zone. The results of the presented research are interesting for specialists in the field of mechanization of agricultural production and farmers who operate universal row-crop tractor self-propelled chassis.

\section{Survey of the recent achievements and contributions}

The arrival of a universal row-crop tractor self-propelled chassis is a result of the technological development of processing agricultural crops. The use of a front technological frame enabled to install the machines and tools in the center zone, in view of the tractor driver, which in its turn made it possible to make the position of a tractor driver's assistant redundant [1-5]. 
However, the high labor intensity of mounting and dismounting hitched tools and machines, especially in the field conditions, led to the fact that the self-propelled chassis began to be used mainly for transport operations with a cargo platform mounted on a technological frame [1].

The desire to increase the versatility of the self-propelled tractor chassis and to ensure the attachment of tools and machines in the center zone led to a number of patent proposals.

Fig. 1 shows a self-propelled chassis with an upper (in relation to the mounted tools) frame [6]. When hitching tools, the frame rotates in a longitudinal-vertical plane, leaning on the outrigger. However, this technical solution complicates the design of the machine and increases its weight.

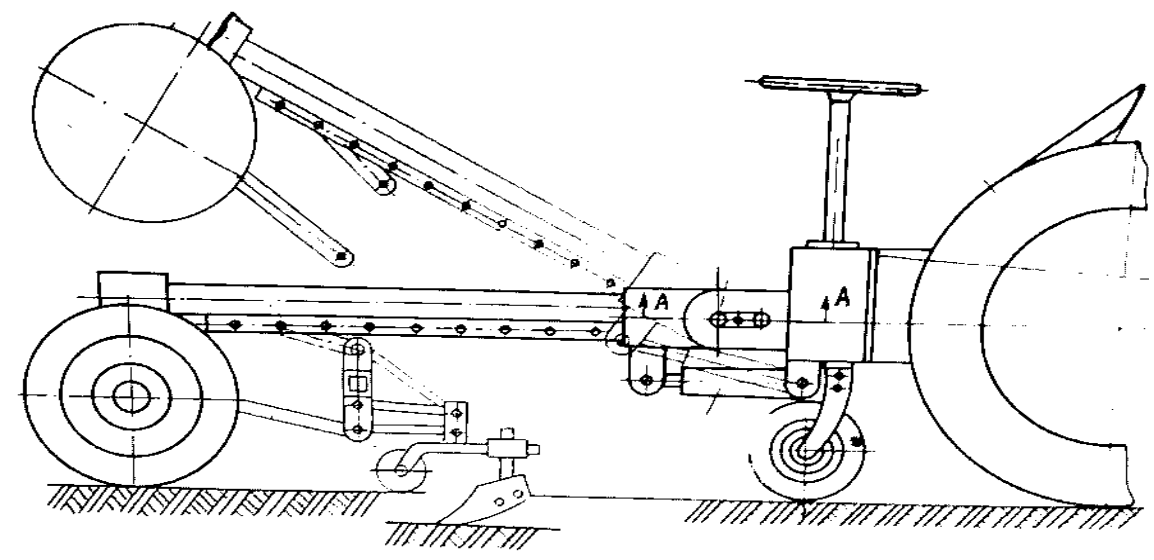

\section{Fig. 1. Self-propelled chassis with an upper (in relation to the mounted tools) frame [6]}

Fig. 2 shows a diagram of a self-propelled chassis with a hinged system on the front swivel axle [1; $2 ; 7 ; 8]$. The front technological frame is made inclined like a "backbone" structure. The front swivel axel ensures hitching by turning it $180^{\circ}$. The disadvantage of this technical solution is that the front axle must have a switching mechanism to provide a transition from the front guide wheels turn to the $180^{\circ}$ turn of the axle.

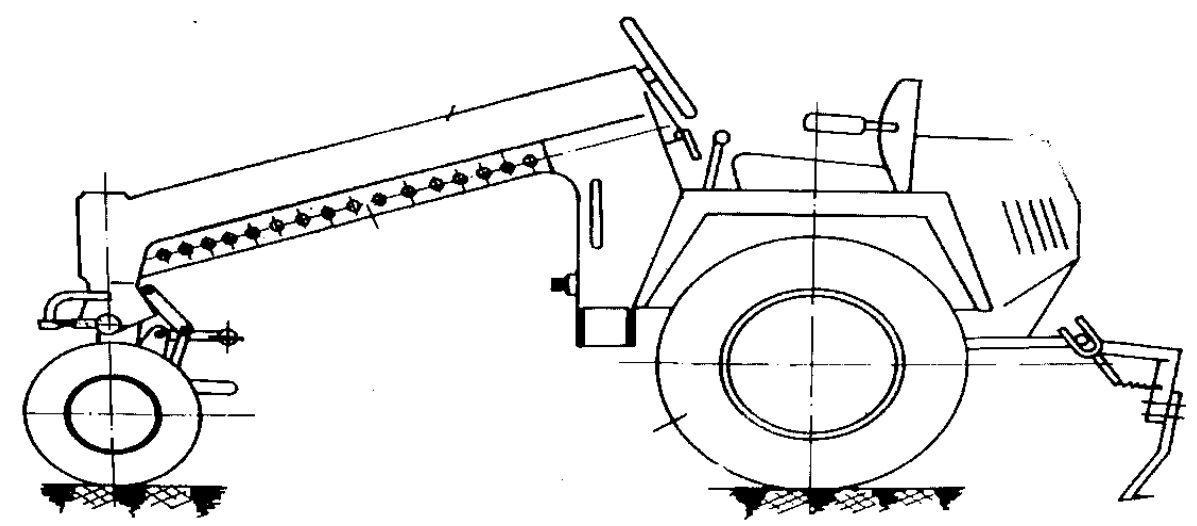

Fig. 2. Diagram of a self-propelled chassis with a hinged system on the front swivel axle $[1 ; 2,7 ; 8]$

In works [1-2], a variant of a folding technological frame is introduced, which allows the conversion from a two-tiered frame with spaced longitudinal spars to a two-tiered frame with contiguous spars.

The analysis of well- known design solutions urged the authors to develop a construction [9] of the front technological frame of a universal tractor self-propelled chassis with a front balancer axle swiveling by $180^{\circ}$ and folding longitudinal spars.

The construction of the "folding" frame allows to freely place the tools in the center zone when the front swing axle with the tool is rotated $180^{\circ}$. In this case, there is no need to rotate the self-propelled chassis by the front guide wheels, you can use the rotation of the front axle as it is enough space under the front beam of the frame. 
Dynamic and mathematical models of turning a wheeled vehicle when turning the front axle are considered in publications $[10 ; 12]$. However, these models were later used to build more complex steering vehicles with swivel guide wheels.

Analysis and classification of possible ways of turning wheeled vehicles are presented in the study [11]. However, in [10; 12], as in other well-known studies, the dynamics of a wheeled vehicle, when turning the front axle suspended by a balancer, is not addressed. We examined this issue in [13]. These issues were not also considered in the works of foreign authors [14-16].

The two degrees of freedom of the front axle in the horizontal and vertical planes allow obtaining an interesting positive effect. It happens due to the reduction of the moment of resistance to turning, which is proportional to the difference in forces to the rolling resistance on the wheels of the left and right sides of the front axle [13]. This improves not only the controllability of the self-propelled chassis but also facilitates the implementation of mechanized hitching of implements and tools in the center zone.

\section{Targets and objectives of the research}

The aim of the study is to increase the maneuverability of the universal-cultivated tractor selfpropelled chassis, including the process of mechanized hitching to the center zone, when using a folding technological frame.

To achieve this goal, it is necessary to solve the following tasks:

- to evaluate the influence of the front wheel track width on the self-propelled chassis maneuverability with the considered turning method;

- to determine the conditions for the possibility of turning the self-propelled chassis around one of the rear wheels (with a minimum radius) when hitching implements and tools in the center zone.

\section{Presentation of the main material}

Fig. 3 shows a diagram of the suggested self-propelled chassis with a hinged system on the front swivel axle and a folding frame [9].
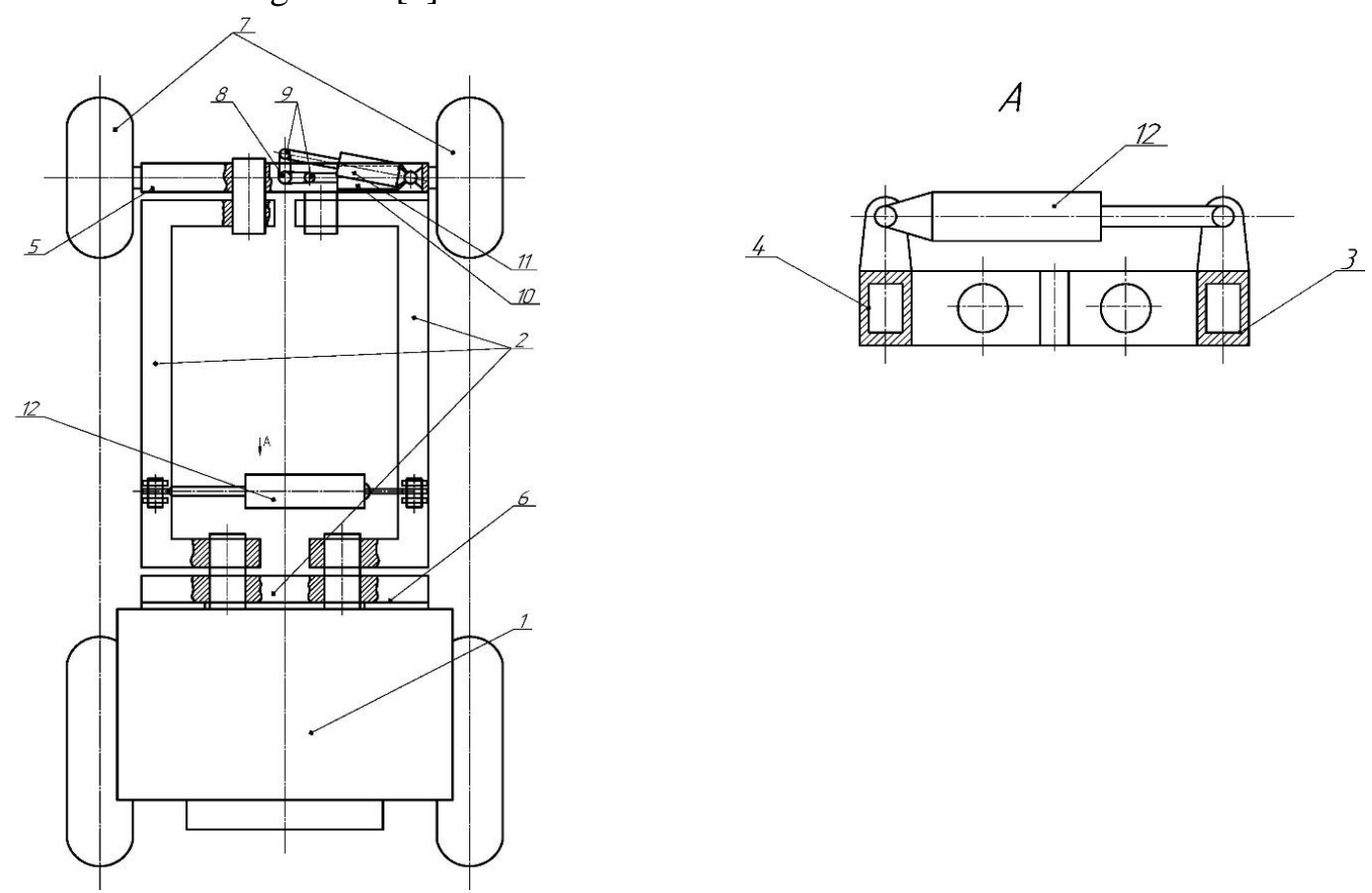

Fig. 3. Self-propelled chassis with a hinged system on the front swivel axle and a folding frame

[9]: $\mathrm{a}$ - top view; $\mathrm{b}$ - view along arrow A; 1 - power unit; 2 - frame; 3.4 - left and right longitudinal C-shaped (swivel) bars; 5, 6 - front and rear bars of the frame; 7 - swivel front axle; 8 - vertical drive shaft of the front axle turning mechanism 7;9-double-armed lever;

$10,11,12$ - control hydraulic cylinders 
The device works as follows: when the fluid pressure is supplied to the hydraulic cylinder 12 , two C-shaped beams 3 and 4 rotate upwards relative to the front 5 and rear 6 bar of the frame, forming a space under the frame 2 for installing mounted implements and tools.

At the same time, pressure is supplied to the hydraulic cylinder 10, which transfers the doublearmed lever 9 from one dead center to another, turning the bridge by 180 degrees. The tools are hung on the rear side of the swing bridge 7. After that, pressure is applied to the opposite cavity pocket of the hydraulic cylinders 12 and 10 and the system returns to its original position.

This construction not only facilitates the process of hitching tools to the center zone, but also increases maneuverability of the self-propelled chassis at any track, since the perpendiculars to the planes of rotation of the front and rear wheels always intersect at the same point $O$, which is the center of rotation (Fig. 4a).

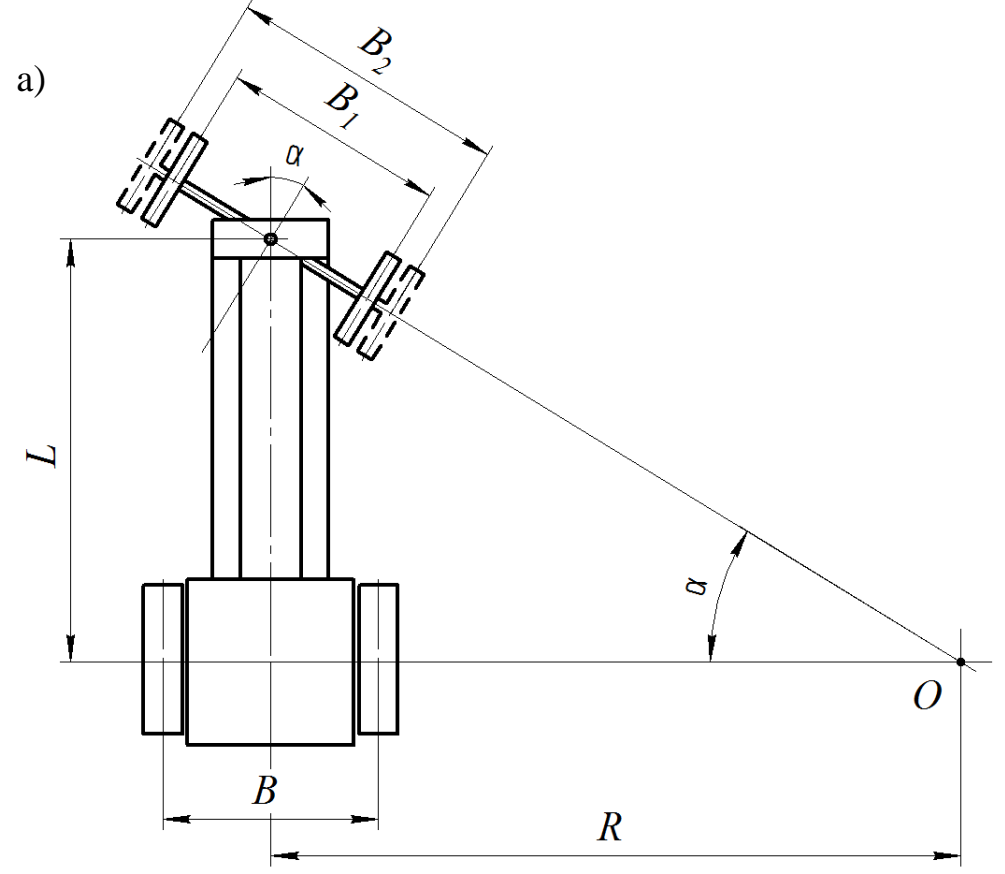

b)

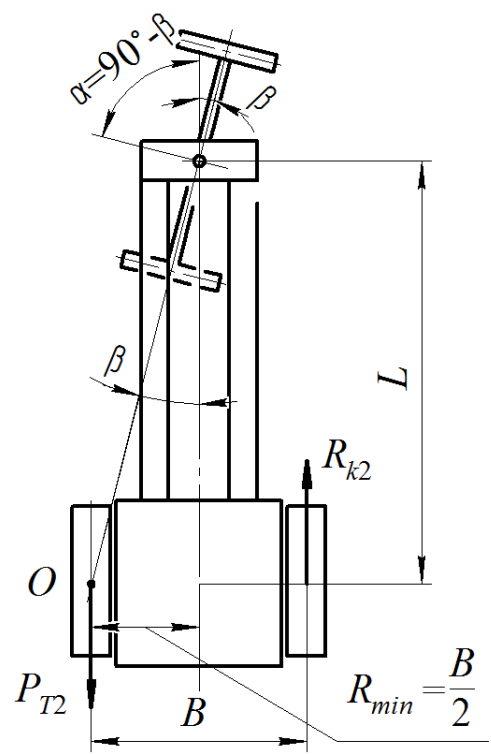

Fig. 4. Schemes of turning a self-propelled chassis with a swivel axle:

$\mathrm{a}$ - with a variable track, $\mathrm{b}$ - around one of the rear wheels 
In addition, the front swivel axle allows turning within the smallest radius.

$$
R_{\min }=\frac{B}{2},
$$

where $B$-track width of the rear wheels.

To make a turn with $R=R_{\min }$, the front axle of the self-propelled chassis must be turned at the angle:

$$
\gamma=90^{\circ}-\beta
$$

where $\beta$-design angle (Fig. 6, b),

$$
\beta=\operatorname{arctg} \frac{B}{2 L},
$$

where $L$-longitudinal wheelbase.

To increase the turning moment (Fig. 4b), it is necessary to brake the inner wheel (it is even desirable to disconnect it from the engine). In this case, the value of the turning moment will be equal to

$$
M_{p o v}=\frac{B}{2}\left(R_{K_{2}}+P_{T_{2}}\right) .
$$

To reach the maximum turning moment $\left(M_{p o v}\right)$ max on the rear wheels, it is necessary that the braking force on the inner wheel and the tangential reaction on the outer wheel equal to the limiting adhesion forces of these wheels, i.e

$$
\begin{gathered}
P_{T_{2}}=\sqrt{\varphi^{2}\left(R_{z^{2}}^{\prime}\right)^{2}-K^{2} R_{\delta_{2}}^{2}}, \\
R_{K_{2}}=\sqrt{\varphi^{2}\left(R_{z^{2}}^{\prime \prime}\right)^{2}-\left(1-K^{2}\right) R_{\delta_{2}}^{2}},
\end{gathered}
$$

where $\varphi$-coefficient of wheel adhesion to the road;

$R_{z^{2}}^{\prime}, R_{z^{2}}^{\prime \prime}$ - normal reaction of road on the inner and outer wheels, respectively;

$R_{\delta}$ - total lateral reaction of road on the rear wheels;

$K$ - proportion of the total lateral road reaction to the inner wheel, (7):

$$
K=\frac{R_{z_{1}}^{\prime}}{R_{z}}
$$

Normal reactions on the rear wheels

$$
\begin{aligned}
& R_{z^{2}}^{\prime}=0.5 R_{z_{2}}-R_{\delta_{2}} \frac{h}{B} ; \\
& R_{z^{2}}^{\prime \prime}=0.5 R_{z_{2}}+R_{\delta_{2}} \frac{h}{B} .
\end{aligned}
$$

The total lateral force acting on the rear axle

$$
R_{\delta_{2}}=\frac{R_{z_{2}}}{g} \omega_{z}^{2} \frac{B}{2},
$$

where $g$-acceleration of gravity, $g=9,81 \mathrm{~m} \cdot \mathrm{s}^{-2}$;

$\omega_{z}$ - angular rate of rotation.

The total lateral force acting on the rear axle.

We calculate the maximum turning moment taking into account (4)-(10)

$$
\left(M_{p o v}\right)_{\max }=\frac{B}{2} R_{Z_{2}} \sqrt{\varphi^{2}-\frac{\omega_{z}^{4}}{4 g^{2}} B^{2}} .
$$

Resistance to turning 


$$
M_{\text {sopr }}=R_{z_{1}} f \sqrt{L^{2}+\frac{B^{2}}{4}}
$$

where $f$-coefficient of rolling resistance of the front wheels;

$R_{z_{1}}-$ total normal reaction of road on the front wheels.

Condition for the possibility of turning the self-propelled chassis with a minimum radius $R_{\min }$

$$
\left(M_{p o v}\right)_{\max } \geq M_{\text {sopr }} \text {. }
$$

\section{Results and discussion}

Thus, in contrast to the previously known technical results, a method of automated attachment of the implements and tools to the center zone of a self-propelled chassis is proposed. The use of a swivel bridge makes it possible to solve both the problem of automated attachment of implements and the problem of ensuring the swing of the bridge.

At the same time, the controllability of the machine is improved regardless of the wheel track. In this case, there is no need for transverse steering rods, which need lengthening or shortening for different tracks. When turning the self-propelled chassis in place (around one of the rear wheels), a dynamic model of rear wheel control is considered. In this situation one wheel is braked, and a traction moment is applied to the second wheel. The conditions for the possibility of an in-place turn have been determined.

\section{Conclusions}

1. The proposed method of aggregating a self-propelled tractor chassis with a swivel axle and a folding frame allows not only to reduce the labor intensity during the process of hitching tools in the center zone, but also to increase the maneuverability of these machines.

2. The research determined that when the front axle is swiveling, the track width does not affect the maneuverability of the self-propelled chassis.

3. The inequality (13) enables us to estimate the possibility of turning the vehicle with a minimum radius relative to one of the rear wheels, which makes it possible to mount the implements and tools into the center zone, when the frame is folding.

\section{References}

[1] Либцис С.Е., Лебединский Г.В., Подригало А.И. Новые компоновочные схемы отечественных и зарубежных промышленных самоходных шасси (New layout diagrams of domestic and foreign industrial self-propelled chassis). Москва: ЦНИИТЭИ тракторосельхозмашин, 1974. 65 p. (In Russian).

[2] Либцис C.Е. Универсально-пропашные самоходные шасси (Universal row-crop self-propelled chassis). Москва: Машиностроение, 1976. 216 p. (In Russian).

[3] Ксеневич И.П., Парфенов А.П., Либцис С.Е. Сельскохозяйственные тракторы нетрадиционных компоновок (Agricultural tractors of unconventional layouts). Минск, 1998. 209 p. (In Russian).

[4] Рославцев А.В. Теория движения тягово-транспортных средств (The theory of motion of traction vehicles). Москва: УМЦ “ТРИАДА”, 2003. 172 p. (In Russian).

[5] Кириченко И.Г. Модульная концепция проектирования технологических машин для строительного производства (Modular concept for the design of technological machines for the construction industry). Харьков: Издательствово ХНАДУ, 2002. 119 p. (In Russian).

[6] Авторское свидетельство СССР №307753. Самоходное шасси с верхним по отношению к навешиваемым орудиям расположением рамы (Self-propelled chassis with an upper frame in relation to the mounted implement). (In Russian).

[7] Авторское свидетельство СССР №206932. Самоходное шасси с навесной системой на переднем поворотном мосту (Self-propelled chassis with hinged system on the front swing axle). (In Russian). 
[8] Авторское свидетельство СССР №242538. Самоходное шасси с навесной системой на переднем поворотном мосту (Self-propelled chassis with hinged system on the front swing axle). (In Russian).

[9] Патент України на корисну модель 146322 МПК А01В 51/02 (2006.01). Самохідне шасі $з$ навісною системою на передньому поворотному мості (Self-propelled chassis with a hinged system on the front swingarm). (In Ukraine).

[10] Подригало М.А., Волков В.П., Кирчатый В.И., Бобошко А.А. Маневренность и тормозные свойства колесных машин (Maneuverability and braking properties of wheeled vehicles). Харьков: Издательство ХНАДУ, 2003. 403 p. (In Russian).

[11] Чайковский И.П., Саломатин П.А. Рулевое управление автомобилей (Steering car). Москва: Машиностроение, 1987. 1989 p. (In Russian).

[12] Бобошко О.А. Підвищення маневреності лісних тракторів і самохідних шасі (Improving the maneuverability of forest tractors and self-propelled chassis): Автореферат дис. канд. техн. наук: 05.22.02. ХНАДУ. Харьков, 2002. 19 p. (In Ukraine).

[13]Подригайло М.А., Бобошко О.А., Разаренов Л.В., Закапко О.Г., Зинченко Е.И., Краснокутский В.Н. Оценка легкости управления передним поворотным мостом перспективного тракторного самоходного шасси (Evaluation of the ease of control of the front swivel axle of a promising tractor self-propelled chassis). Вісник національного технічного університету “ХПІ”. Серія: Машинознавство та САРП, 2020, № 2. pp. 84-89. (In Russian).

[14] Entwicklung einer Überlagerung - Lenzing (Overlay development - Lenzing). Dick Wolfang, Holle Michael. ATZ. Automobiltechn, 2003, № 5. pp. 448-450, 452, 454, 456. (In Germane).

[15] Rear-steer rigid to confound the normal distribution curve. Wilcox David. Transp. Eng. 2003. pp. 30-32. (In English).

[16] Legouis T., Gosseling C., Bourassa P., Lanevile A. Etude paramétrique de la stabilité dynamique du système vehicle/pilote (A parametric study of the dynamic stability of the vehicle/pilot system). Yndeniere automobile, 1985. pp. 78-83. (In French). 